\title{
Longitudinal Relationship Between Adolescent's Depression and Delinquency: The Effect of Parents, Peer and Teacher Factors
}

\author{
Ji Ah Son, Sun Hee Kim \\ Department of Child \& Family Studies, Pusan National University, Pusan, Korea \\ 청소년의 우울과 비행의 종단적 관계 : 부모, 또래 및 교사요인의 영향 \\ 손지아, 김선희 \\ 부산대학교 아동가족학과
}

Objective: The purpose of this study was to examine the developmental trajectories of adolescent depression and delinquency, to explore the longitudinal relationship between depression and delinquency, and to investigate the effects of parental abuse, parent neglect, delinquent peer association, and teacher relationships on the longitudinal relationship between depression and delinquency.

Methods: The participants of this study were 2,179 students from the second to sixth waves of longitudinal data from the Panel Study on Korean Children. The data were analyzed using latent growth modeling.

Results: First, the trajectory of adolescent depression decreased slightly, whereas delinquency increased across time. Second, the initial level of depression indicated a significant negative effect on the slope of delinquency. Third, the intercept of depression was affected by parental abuse, parental neglect, and teacher relationships. Further, the slope of depression was only influenced by parental abuse. Fourth, the intercept of delinquency was affected by parental abuse, delinquent peer association, and teacher relationships. Further, the slope of delinquency was influenced by parental abuse, parental neglect, and delinquent peer association.

Conclusion: These findings suggest the importance of interventions targeting parental abuse and neglect to prevent adolescent depression and delinquency.

Keywords: adolescents depression and delinquency, parental abuse, parental neglect, delinquent peer association, teacher relationship

\begin{abstract}
서론
청소년기는 신체, 심리, 사회적 측면의 급격한 변화로 인해 내 적 혼란과 외적 상황에 대한 갈등으로 불편한 심리상태를 경 험하는 시기이다(Rathi \& Rastogi, 2007). 이러한 상태는 스트 레스를 유발하여 우울과 같은 정서적 문제를 야기할 뿐 아니

Corresponding Author: Sun Hee Kim, Department of Child Development \& Family Studies, Pusan National University, 2, Busandaehak-ro 63beongil, Geumjeong-gu, Busan, Korea

E-mail: kremedy@pusan.ac.kr
\end{abstract}

라 부정적 정서를 다루는 능력의 부족으로 인해 충동적이거 나 공격적인 행동으로 표출되기도 한다(Glaser, 1967). 청소년 기 대표적인 부적응 특성인 우울과 비행을 적절히 다루지 못 할 경우 이후 성인기까지 지속적인 영향을 미칠 가능성이 높 아 이들의 발달과정에 주목할 필요가 있다(Rudolph, Flynn, Abaied, Groot, \& Thompson, 2009). 최근 일부 연구자들은 청

(C)The Korean Association of Child Studies

This is an Open Access article distributed under the terms of the Creative Commons Attribution Non-Commercial License (http:// creativecommons.org/licenses/by-nc/4.0) which permits unrestricted noncommercial use, distribution, and reproduction in any medium, provided the original work is properly cited. 
소년기 우울과 비행의 발달궤적을 종단적으로 규명하고자 시 도하고 있다. 우선 중·고등학교 시기 우울의 발달궤적에 관한 종단연구를 살펴보면, 청소년의 우울, 불안, 사회적 위축 같은 내재화 증상은 15 세부터 18 세까지 지속적으로 증가함을 보고 하거나(W. Min \& Lee, 2015), 청소년기 우울증상이 15세에서 16 세에 정점을 이루다가 시간이 흐름에 따라 감소함을 보여 주고 있다(Cho, 2009; S. W. Lim, 2013). 한편 비행의 발달궤적 을 살펴보면, 청소년의 일탈과 공격성이 15 세에서 18 세까지 꾸준히 증가하거나(J. R. Lee, 2008) 비행이 15세에서 17세까지 는 감소하는 형태를 보이다가 이후 19세까지는 다시 증가하 는 U자 형태를 보였다(S.-H. Jung, 2009). 이와 같이 청소년기 우울과 비행은 시간의 흐름에 따라 지속적으로 증가 혹은 감 소하거나 또는 증가 후 감소 혹은 감소 후 증가 등 보다 다양한 패턴을 보이는 것으로 나타났다. 이는 중학생에 비해 고등학 생이 우울, 비행의 수준이 더 높다는 기존의 횡단연구와는 다 른 결과를 보여주는 것이다(Koo, 2004). 기존의 횡단연구는 동 일 시점에 다른 대상을 비교한 것으로 우울과 비행이 시간이 지남에 따라 어떠한 발달궤적을 보이는지 정확하게 반영한 것 이라고 볼 수 없다. 이에 본 연구에서는 중학생부터 고등학생 시기까지 우울과 비행이 각각 어떠한 형태로 발달하는지를 살 펴보고자 한다.

또한, 청소년의 우울과 비행은 각각 상이한 부적응 특성임 에도 불구하고 이들의 발달과정은 밀접한 관련성이 있다. 우 울증상을 보이는 $45 \%$ 의 청소년이 품행장애를 동시에 보이 거나(K.-N. Lee, 2003), 비행이나 공격성의 수준이 높은 아동 이 우울을 동반할 가능성이 더 높은 것으로(Gilliom \& Shaw, 2004) 보고되고 있다. 선행연구들에서는 우울과 비행 간의 관 련성을 행동화 모델로 설명하거나 실패모델로 설명하고 있다. 먼저 실패 모델을 주장하는 연구자들은 비행에 의해 야기된 학업성취와 대인관계 등의 발달적 실패경험이 이후 시기 우울 의 위험요소로 작용하는 관계한다고 주장한다(Capaldi, 1991; S. Lee \& Heo, 2015; W. Min \& Lee, 2015). 반대로 행동화 모델 을 주장하는 연구자들은 우울과 관련된 부정적 정서가 주변 사람들과의 갈등과 적대감을 유발시켜 이후 비행행동으로 이 어지기도 한다는 것을 밝히고 있다(S. W. Lim, 2013; Wiesner, 2003). 이러한 연구들은 우울이 비행에 미치는 영향 혹은 비행 이 우울에 미치는 영향을 규명함으로써 우울과 비행 간의 일 방적인 인과관계를 가정한다. 반면 최근 연구자들은 우울과 비행 간의 양방적 인과관계를 지지한다. 즉 초기의 비행은 발 달적 실패경험을 야기하여 우울 수준을 증가시키고, 이러한 증가된 우울 수준은 다시 보다 더 심각한 비행행동을 야기한
다(Patterson, Reid, \& Dishion, 1992). 또한 잠재성장분석을 통 해 초기의 우울이 시간의 흐름에 따른 비행의 변화율에 영향 을 미치거나 혹은 초기의 비행이 시간의 흐름에 따른 우울 변 화율에 영향을 미친다고 보고되고 있다(Gilliom \& Shaw, 2004; Leadbeater, Thompson, \& Gruppuso, 2012; E.-J. Lee, 2010). 즉 청소년기 우울과 비행은 각기 개별적으로 발달하기 보다는 상 호 영향을 미치면서 발달하는 특성으로 추정된다. 따라서 청 소년기 우울과 비행에 대한 예방적 혹은 치료적 개입을 위해 서 시간의 흐름에 따른 청소년의 우울 및 비행의 발달적 변화 를 이해하고 이들 간의 상호적 관련성을 규명하는 종단적인 접근이 요구된다

한편 최근 일부 연구자들(E.-J. Lee, 2010; J.-Y. Lee, 2010) 은 우울과 비행이 상호간에 영향을 미치는 방식으로 발달하 는데 기여하는 개인, 부모 및 가족과 같은 예측요인들의 영향 력을 규명하고 있다. J.-Y. Lee (2010)는 개인의 기질 중 자극추 구기질이 중학교 1,2 학년 청소년의 우울과 비행의 공존발달 에 영향을 미침을 밝혔고, E.-J. Lee (2010)는 잠재성장모형 분 석을 통해 부모학대가 초등학교 4학년 아동의 내재화 및 외현 화 문제의 초기치 뿐 아니라 초등학교 4학년에서 중학교 1학 년에 이르는 동안의 내재화 및 외현화 문제의 변화율에도 영 향을 미침을 확인하였다. 그러나 이 연구들은 개인요인과 부 모요인만을 살펴보았을 뿐 또래, 학교와 같은 가족 외적인 요 인들의 영향력을 간과하였다. 생태학적 관점에 의하면 청소년 의 우울과 비행 등의 부적응을 이해함에 있어서 개인과 환경 을 분리하여 이해하기 보다는 다양한 환경간의 상호작용 관계 속에서 부적응의 주요 원인이 무엇인지 밝히는 것이 필요하다 (Bronfenbrenner, 1979). 따라서 본 연구에서는 청소년기 우울 과 비행의 상호적 관련성에 영향을 미치는 부모, 또래, 교사요 인의 영향력을 함께 살펴보고자 한다.

부모의 부적절한 양육태도는 청소년기 우울과 비행 발달 에 영향을 미치는 가장 대표적인 환경적 요인이다(Lansford et al., 2007). 특히 Bowlby (1958)의 애착이론에 따르면 부모의 양 육태도 중 부모학대와 방임은 자녀로 하여금 부모에 대해 불 만족스러움을 경험하게 하고 이로 인해 자녀는 자신이나 타인 에 대해 부정적인 상을 형성한다고 하였다. 실제로 자녀에 대 해 부모가 감독하지 않고 관심을 보이지 않을 때 자녀는 더욱 우울 및 불안감을 느끼고(J. Y. Kim \& Choi, 2012), 공격성과 비행행동을 포함한 더 많은 행동문제를 보였다(Lansford et al., 2007; A.-Y. Lee \& Yoo, 2011). 또한 E.-J. Lee (2010)는 부모학대 및 방임은 청소년기 우울과 비행 모두에 공통적으로 작용하는 위험요인임을 확인하였다. 
또한, 청소년기는 1 차적 상호작용 대상이었던 부모를 벗 어나서 또래와의 상호작용이 중요해지는 시기이다. 이 시기 에는 청소년들이 자신의 행동을 결정할 때 부모 보다 또래와 의 상호작용이 더 중요하게 작용한다(Kim et al., 2013). 이들은 자신들이 속해있는 집단이 비행에 수용적일 경우 또래의 비 행을 학습하게 될 가능성이 높아지며(J. W. Lee, 2013; Y. Son, 2016), 비행친구와 교류할수록 범죄, 약물 사용 등의 외현화 행동이 증가하게 되고 이와 더불어 우울과 같은 내재화 문제 또한 유발된다(Fergusson, Wanner, Vitaro, Horwood, \& SwainCampbell, 2003). 따라서 또래요인 중 비행친구와의 잦은 교류 는 청소년들의 우울과 비행의 종단적 관계에 영향을 미칠 것 으로 예상된다.

마지막으로 청소년들은 하루 중 대부분의 시간을 학교에 서 생활하기 때문에 학교 내 교사와의 관계 또한 중요하다. 교 사관계는 수업을 포함한 학교생활 전반적인 적응을 도울 뿐 아니라 청소년들의 사회적 상호작용을 촉진하는데 중요한 영 향을 미친다(Joo \& Lee, 2012). 관련 종단연구에 의하면 Sin과 Hwang (2016)은 중학교 1학년에서 고등학교 1학년을 대상으 로 자기회귀교차지연 모형을 이용하여 이전시점의 교사관계 를 포함한 학교생활적응이 원만할수록 이후시점의 우울을 낮 추는 효과가 있다고 밝혔다. 또한 Park (2011)의 연구에서는, 잠재성장모형을 적용하여 중학교 2학년 시점 교사애착이 높 을수록 중학교 2학년에서 고등학교 3학년까지 학교부적응 이 완만하게 감소하고 있다는 것을 밝혔다. 즉 교사와의 긍정 적인 관계는 이후 청소년의 사회 및 학업적 유능성을 향상시 킬 뿐만 아니라 공격적인 행동과 비행 등을 포함한 문제행동 (J. K. Lee, 2012; Liljeberg, Eklund, Fritz, \& Klinteberg, 2011)과 우울증과 같은 내재화 문제를 예방하였다(Herrero, Estévez, \& Musitu, 2006). 따라서 청소년의 정서 및 행동문제에 보호적인 역할을 하는 요인으로 교사관계를 살펴보고자 한다.

종합해보면 우울과 비행은 청소년기 대표적인 부적응 특 성으로서 이후 발달에 지속적으로 부정적 영향을 미치게 되 므로 이를 예방하고 치료하기 위한 실천적 정보를 제공할 필 요가 있다. 따라서 본 연구에서는 중학교에서 고등학교 시기 까지 우울과 비행 각각의 발달궤적을 살펴보고, 우울과 비행 의 발달궤적간 종단적 관계를 규명하고자 한다. 뿐만 아니라 이에 영향을 미치는 예측요인으로 부모의 학대 및 방임, 비행 친구, 교사관계를 살펴봄으로써 청소년의 문제행동에 대한 다양한 환경적 요인들의 영향력을 검증하고자 한다. 이를 통 해 청소년의 우울과 비행을 유발하는 위험요인을 파악함으로 써 잠재적으로 우울 및 비행에 취약할 수 있는 청소년들을 조
기에 선별하고 이를 예방할 수 있는 실질적인 개입전략을 수 립하는데 도움을 줄 수 있을 것이다. 본 연구의 연구문제는 다 음과 같다.

\section{연구문제 1}

청소년기 우울과 비행의 발달궤적은 어떠한가?

\section{연구문제 2}

청소년기 우울과 비행의 발달궤적간의 종단적 관계는 어떠한가?

\section{연구문제 3}

청소년기 우울과 비행의 발달궤적간의 종단적 관계에 대한 부모 (부모학대 및 방임), 또래(비행친구) 및 교사요인(교사관계)의 영향은 어떠한가?

\section{연구방법}

\section{연구대상}

본 연구는 한국청소년정책연구원의 한국아동.청소년패널조 사(Korean Children and Youth Panel Survey [KCYPS]) 중 중1 패 널자료를 사용하였다(National Youth Policy Institute [NYPI], 2012-2016). 중1 패널자료는 전국의 중학교 1학년을 대표하 는 표본을 선정한 뒤 2010년부터 2016년까지 7년 동안 매년 1 회씩 반복·추적 조사한 것으로 개인의 성장 및 이를 둘러싼 환 경 등에 대한 요인으로 구성되어 있다. 본 연구에서는 중학교 2학년, 3학년, 고등학교 1학년, 2학년, 3학년 시점에서 측정된 2차 연도(2011년) 6차 연도(2015년) 자료를 사용하였다. 연 구대상은 원표본 2,351 명 중에서 모든 연도에 조사에 참여하 지 않은 경우와 우울과 비행을 5년 동안 경험하지 않은 경우를 제외한 2,179 명이다. 이 중 남학생은 1,108 명(50.8\%)이고 여 학생은 1,071 명(49.2\%)이다. 부의 교육수준은 고등학교 졸업 이 $36.8 \%$, 대학교 졸업이 $36.6 \%$ 로 나타났으며, 전문대 졸업이 $9.1 \%$, 대학원 졸업이 $3.7 \%$, 중학교 졸업 및 그 이하가 $2.9 \%$ 순 으로 나타났다. 모의 교육수준은 고등학교 졸업 $49.2 \%$, 대학 교 졸업 $27.2 \%$, 전문대 졸업 $9.6 \%$, 중등 졸업 및 이하가 $2.6 \%$, 대학원 졸업이 $1.7 \%$ 순으로 나타났다. 그리고 가정의 연간 가 구소득은 3,000-5,000만원 미만이 38.6\%, 5,000-7,000만원 미 만이 21.4\%, 1,000-3,000만원 미만이 $17.9 \%, 7,000$ 만원 이상 이 $14.5 \%, 1,000$ 만원 미만이 $1.7 \%$ 로 나타났다. 


\section{연구도구}

\section{우울}

우울 척도는 G. I. Kim, Kim과 Won (1984)이 개발한 간이정신 진단검사 중 우울척도를 수정.보완한 질문지로 총 10 문항으 로 구성되어 있다. "나는 죽고 싶은 생각이 든다.", "나는 모든 일에 관심과 흥미가 없다.” 등의 문항이 포함되며, 4점 Likert 척도(매우 그렇다[1] 전혀 그렇지 않다[4])로 구성되어 있다. 본 연구에서는 해석상의 편의를 위해 역코딩하여 점수를 산출 하였으므로 점수가 높을수록 청소년의 우울 수준이 높음을 의 미한다. 우울이 측정되지 않은 5 차 년도를 제외한 각 시점의 내적합치도 계수(Cronbach's $\alpha$ )는 2차 연도 .90, 3차 연도 .90, 4 차 연도 $.88,6$ 차 연도 .87 로 나타났다.

\section{비행}

비행 척도는 J.-H. Kim과 Lee (1995)가 개발한 비행척도를 참 고하여 재구성하여 일탈 및 비행 관련 문항을 수정-보완한 것으로 총 14 문항으로 구성되어 있다, 본 연구에서는 2 차년도 조사에서 누락된 1 문항(“돈을 걸고 도박 게임하기”)을 제외하 고 총 13 문항을 사용하였다. 문항으로는 담배피우기, 술 마시 기, 남을 심하게 놀리거나 조롱하기, 무단결석, 가출, 폭행, 남 의 돈이나 물건 훔치기, 협박하기, 집단따돌림(왕따)시키기, 성관계, 성폭행이나 성희롱하기 등의 내용이 포함되어 있다. 각 문항은 지난 1 년 동안 관련 비행 행동을 했는지에 대해 있 다(1) 혹은 없다(2)로 답하도록 구성되어 있다. 본 연구에서는 해석상의 편의를 위해 있다(1), 없다(0)로 역코딩하였다. 각 시 점의 내적합치도 계수(Cronbach's $\alpha$ )는 2차 연도에 .67, 3차 연 도 .65, 4차 연도 .56, 5차 연도 .57, 6차 연도 .50으로 나타났다.

\section{부모학대}

부모학대 척도는 Heo (2000)와 S. Kim (2003)의 척도 중 학대 와 관련된 문항을 재구성한 척도로 총 4 문항이다. 각 문항은 "내가 무언가 잘못했을 때 부모님께서는 정도 이상으로 심하 게 혼내신다.", "내가 잘못하면 부모님께서는 무조건 때리려 고 하신다.", "내 몸에 멍이 들거나 상처가 남을 정도로 부모 님께서 나를 심하게 대하신 적이 많다.", "부모님께서는 나에 게 심한 말이나 욕을 하신 적이 많다.”이며, 4점 Likert 척도(매 우 그렇다[1] 전혀 그렇지 않다[4])로 구성되어 있다. 본 연
구에서는 해석상의 편의를 위해 역코딩하여 점수가 높을수 록 부모학대 수준이 높음을 말한다. 2 차 연도 내적합치도 계수 (Cronbach's $\alpha$ )는 .84로 나타났다.

\section{부모방임}

부모방임 척도는 Heo (2000)와 S. Kim (2003)의 척도 중 방임 관련 문항을 토대로 재구성한 척도로서 총 4 문항이다. 문항은 "다른 일보다 나를 더 중요하게 생각하신다.", "내가 학교에서 어떻게 생활하는지 관심을 갖고 물어보신다.", "내 몸이나 옷, 이불 등이 깨끗하도록 항상 신경 쓰신다.", “내가 많이 아프면 적절한 치료를 받게 하신다.”로 구성되어 있으며, 4점 Likert 척 도(매우 그렇다[1] 전혀 그렇지 않다[4])이다. 본 연구에서는 해석상의 편의를 위해 역코딩하여 점수가 높을수록 부모방임 수준이 높음을 말한다. 2차 연도 내적합치도 계수(Cronbach's $\alpha)$ 는 .76으로 나타났다.

\section{비행친구}

비행친구 척도는 '지난 1 년간 비행 경험이 있는 친구의 수' 로 구성되어 있으며, 각 문항에는 앞서 제시한 비행 척도에서 사 용한 13 가지 유형의 비행 항목에 대해 지난 1 년간 그러한 행 동을 한 친한 친구가 몇 명이나 되는지 응답하게 하였다. 각 문항에 대해 1 명이라도 친한 친구가 있다고 응답한 경우 비 행친구가 있다로 간주하였으며, 각 문항에 대해 한명도 없다 고 응답한 경우 비행친구가 없다로 처리하였다. 본 연구에서 는 비행친구 변인을 가변수(dummy variable)로 전환하여 없다 는 0 , 있다는 1 로 부호화하여 분석하였으며 13 문항의 가변수 를 합산하여 분석에 사용하였다. 2차 연도 내적합치도 계수 (Cronbach's $\alpha)$ 는 .87로 나타났다.

\section{교사관계}

교사관계 척도는 한국 아동.청소년 패널조사(KCYPS)의 학교 적응 척도의 하위요인인 교사관계 척도이다. 이는 B. S. Min (1991)의 척도를 한국청소년정책연구원의 패널조사단이 수정, 보완하여 사용한 것이다. 교사관계는 "선생님을 만나면 반갑 게 인사한다.”, “선생님과 이야기하는 것이 편하다.” 등이 포함 된 5개 문항으로 4점 Likert 척도(매우 그렇다[1] 전혀 그렇지 않다[4])이다. 본 연구에서는 해석상의 편의를 위해 역코딩하 여 점수를 산출하였으므로 점수가 높을수록 교사관계가 원만 
함을 의미한다. 2 차 연도 내적합치도 계수(Cronbach's $\alpha$ )는 .83 으로 나타났다.

\section{연구절차}

본 연구에서 사용한 한국청소년정책연구원의 아동 - 청소년 패널조사(KCYPS)의 표본은 2010년 기준 전국 초등학교 1학 년, 4학년, 중학교 1학년을 모집단으로 하여 다단층화집락표 집방식으로 추출되었다. 목표 표본은 6,600 명이었고 전국에 있는 초등학교 1학년, 4학년 그리고 중학교 1학년의 학생 수 에 비례하여 지역별 표본 수를 할당하였다. 다음으로 16 개의 광역시 및 도시를 교차 추출하여 27 개의 집락을 확보하였고 이를 확률비례추출법에 근거하여 학교를 선정하였다. 위와 같 은 절차를 통해 2010년도에 조사가 완료된 표본은 총 7,071명 이었으며, 이 중 중 1 패널에 해당하는 표본은 2,351 명이었다. 본 연구에서는 청소년의 우울과 비행의 발달궤적과 이에 영향 을 미치는 부모, 또래, 교사 요인을 밝히고자하는 목적에 따라 우울과 비행이 측정되지 않은 1 차 연도 자료를 제외하고 2 차 연도에서 6차 연도 자료를 사용하였다.

\section{자료분석}

본 연구에서는 우울과 비행의 발달궤적 간 관계, 그리고 이들 관계에 영향을 미치는 부모학대 및 방임, 비행친구, 교사관계 의 효과를 규명하기 위해 잠재성장모델을 적용하여 5 년 종단자 료를 분석하였다. 청소년의 우울과 비행 및 예측변인들의 특성 을 알아보기 위해 기술통계를 실시하였으며, 청소년의 우울과 비행의 발달궤적을 확인하기 위해 단변량잠재성장모형 분석을 실시하였다. 또한 다변량 잠재성장모델을 설정하여 우울과 비 행의 종단적인 관계를 파악하였다. 마지막으로 우울과 비행의 다변량 잠재성장 모델에 기초하여 예측요인(부모의 학대 및 방 임, 비행친구, 교사관계)을 포함한 다변량 조건모델을 검증하 였다. 이를 위해 SPSS 23.0 프로그램(IBM Co., Armonk, NY)과 Amos 23.0 프로그램(IBM Co., Armonk, NY)을 사용하였다.

\section{연구결과}

\section{주요 변인들의 기술 통계 및 상관 분석}

본 연구의 주요 변인인 각 시점별 청소년의 우울 및 비행 그리
Table 1

Descriptive Statistic Analysis

\begin{tabular}{ccccc}
\hline Variables & $M$ & $S D$ & Skewness & Kurtosis \\
\hline Depression & & & & \\
Time 1 & 1.94 & .61 & .28 & -.26 \\
Time 2 & 1.99 & .62 & .20 & -.30 \\
Time 3 & 1.88 & .55 & .16 & -.45 \\
Time 5 & 1.87 & .54 & .22 & -.28 \\
Delinquency & & & & \\
Time 1 & .23 & .52 & 2.20 & 4.23 \\
Time 2 & .19 & .48 & 2.45 & 5.52 \\
Time 3 & .24 & .52 & 1.86 & 2.29 \\
Time 4 & .32 & .57 & 1.45 & .79 \\
Time 5 & .39 & .58 & 1.07 & -.18 \\
Parental abuse & & & & \\
Time 1 & 1.84 & .71 & .96 & .51 \\
Parental neglect & & & & \\
Time 1 & 1.85 & .55 & .25 & .41 \\
Deliquent peers & & & & \\
Time 1 & 1.18 & 2.31 & 2.62 & 7.37 \\
Teacher relationship & & & & \\
Time 1 & 2.79 & .66 & -.12 & -.14 \\
\hline
\end{tabular}

Note. Time $1=2$ nd in middle school; Time $2=3$ rd in middle school; Time 3 = 1st in high school; Time $4=2$ nd in high school; Time $5=3$ rd in high school.

a Adolescents' delinquency is presented as Square root value

고 초기 시점인 2 차 연도 부모학대, 부모방임, 비행친구, 교사 관계의 평균, 표준편차, 왜도, 첨도를 살펴본 결과는 아래와 같 다(Table 1).

먼저 중2 (Time 1) 우울의 평균점수는 1.94 에서 중학교 3학 년(Time 2)때 1.99로 증가하였으나 이후 고등학교 3학년(Time 5)때 1.87 까지 감소하는 모습을 보였으며, 점수 범위가 최소 1 점에서 최대 4점으로 보았을 때 평균이 다소 낮게 나타났다. 비행의 경우 중학교 2 학년(Time 1) 때는 .23에서 중학교 3 학년 (Time 2) 때 .19로 감소하였으나 이후 고등학교 3학년(Time 5) 때 .39까지 계속해서 증가하는 모습을 보였으며, 점수 범위가 최소 0 점에서 최대 1 점일 때 비행 또한 평균이하로 나타난 경 향이 있다. 부모학대, 부모방임, 비행친구, 그리고 교사관계의 평균은 각각 $1.84,1.85,1.18,2.79$ 였다.

본 연구의 주요 변인들의 정규성 가정이 충족되는지를 확 인하기 위해 왜도 및 첨도를 살펴본 결과 중3(Time 2) 시점의 비행의 왜도값과 첨도값이 각각 4.70 및 31.21 로, 왜도의 절 대값이 3 미만, 첨도의 절대값이 10 미만이라는 정규성 기준 (Kline, 2015)을 충족하지 않았다. 이 경우 정규성 가정에 맞는 
분포로 변환시키기 위해 자료에 적당한 멱수(power)를 적용할 수 있다(Chung, Lee, \& Lee, 2005). 따라서 비행 변인에 대해 제 곱근 변환을 실시하여 데이터의 정규성을 충족시켰다. 그 외 청소년의 우울, 부모의 학대 및 방임, 비행친구 그리고 교사관 계 변인의 왜도 및 첨도의 절대값은 기준을 충족하여 측정치 들이 정규분포를 이루고 있음을 확인하였다.

Table 2에는 주요 변인들의 상관관계를 파악하기 위해 Pearson 상관계수를 산출하였다. 먼저 중2(Time 1)우울은 중 3(Time 2)우울에서 고3(Time 5)우울, 중2(Time 1)비행, 중 3(Time 2)비행, 부모방임, 부모학대와는 통계적으로 유의한 정적상관을 교사관계와는 통계적으로 유의한 부적상관을 나 타내었다. 또한 중2(Time 1)비행은 중3(Time 1)비행에서 고 3(Time 5)비행, 중2(Time 1)우울, 고1(Time 3)우울, 고3(Time 5)우울, 부모학대, 비행친구와는 유의미한 정적상관을 교사관 계와는 부적상관을 나타내었다.

\section{청소년기 우울과 비행의 발달궤적}

청소년 우울과 비행의 최적의 모형을 선택하기 위해 무 변화 모형, 선형변화모형, 이차곡선변화모형의 적합도를 분석하여 살펴보았다. 청소년 우울과 비행의 잠재성장 모형 적합도 통 계치는 Table 3 과 같다. 먼저 우울의 경우 청소년 우울의 초기 치만 있고 변화율은 설정하지 않은 즉, 5 년 동안(2, 3, 4, 6차 연
도) 변화가 없다고 가정한 무변화모형은 NFI, TLI, CFI가 모두 .90 이하이며 RMSEA값이 .10으로 낮은 수준의 적합도를 보여 적절한 모형으로 판단하기 어렵다. 또한 이차곡선변화모형은 $\mathrm{NFI}, \mathrm{TLI}$ 와 CFI 값은 양호하나 RMSEA값이 .10으로 적합한 모형으로 판단할 수 없다. 반면, 청소년의 우울이 5년 동안 선 형으로 변화한다고 가정한 선형변화모형은 $\chi^{2}$ 값은 130.81 로 크나, NFI값(.93)와 TLI값(.92) 그리고 CFI값(.93), RMSEA값 (.08)이 적합도가 좋아 본 연구에서는 최종적으로 청소년 우울 의 발달궤적 모형으로 선형변화모형을 선택하였다.

다음으로 청소년 비행의 3가지 모형에 대한 적합도를 비교 한 결과, 무변화 모형의 경우 NFI, TLI, CFI값이 모두 .90 이하 이며 그리고 RMSEA값은 .12로 적합도 수치가 낮아 적절한 모 형으로 판단하기 어려웠으며, 선형변화모형 $\left(\chi^{2}=144.37, d f=\right.$ $14, p<.001 ; \mathrm{NFI}=.93, \mathrm{TLI}=.94, \mathrm{CFI}=.94, \mathrm{RMSEA}=.06$ )과 이차곡선변화모형 $\left(\chi^{2}=51.99, d f=10, p<.001 ; \mathrm{NFI}=.97\right.$, TLI $=.97, \mathrm{CFI}=.98, \mathrm{RMSEA}=.04)$ 의 적합도가 가장 좋게 나타났 다. 이럴 경우 두 모형은 내포모형관계가 아니므로 카이제곱 차이검증을 통한 모형비교가 불가능하다. 그러므로 더 좋은 적합도 지수를 보이는 모형을 선택해야 하는데, 둘 이상의 모 형을 비교할 때, 모형들 간의 자유도가 다를 경우 모형의 적합 도와 간명성을 고려하는 RMSEA 또는 TLI를 이용해야 한다 (Hong, 2000).

이를 통해 선형변화모형과 이차곡선변화모형을 비교한 결

\section{Table 2}

\section{Correlations Between Variables}

\begin{tabular}{|c|c|c|c|c|c|c|c|c|c|c|c|c|c|}
\hline Variables & 1 & 2 & 3 & 4 & 5 & 6 & 7 & 8 & 9 & 10 & 11 & 12 & 13 \\
\hline 1. Depression (Time 1) & - & & & & & & & & & & & & \\
\hline 2. Depression (Time 2) & $.48^{* *}$ & - & & & & & & & & & & & \\
\hline 3. Depression (Time 3) & $.40^{* *}$ & $.48^{* *}$ & - & & & & & & & & & & \\
\hline 4. Depression (Time 5) & $.36^{* *}$ & $.42^{* *}$ & $.52^{* *}$ & - & & & & & & & & & \\
\hline 5. Delinquency (Time 1) & $.09^{* *}$ & .04 & $.07^{* *}$ & $.05^{*}$ & - & & & & & & & & \\
\hline 6. Delinquency (Time 2) & $.05^{*}$ & $.09^{* *}$ & $.07^{* *}$ & $.06^{* *}$ & $.41^{* *}$ & - & & & & & & & \\
\hline 7. Delinquency (Time 3) & .00 & .04 & $.07^{* *}$ & .01 & $.34^{* *}$ & $.40^{* *}$ & - & & & & & & \\
\hline 8. Delinquency (Time 4) & .01 & .02 & .03 & .03 & $.32^{* *}$ & $.38^{* *}$ & $.50^{* *}$ & - & & & & & \\
\hline 9. Delinquency (Time 5) & .00 & .00 & .00 & $.07^{* *}$ & $.28^{* *}$ & $.30^{* *}$ & $.40^{* *}$ & $.53^{* *}$ & - & & & & \\
\hline 10. Parental neglect (Time 1) & $.21^{* *}$ & $.24^{* *}$ & $.18^{* *}$ & $.15^{* *}$ & .04 & .03 & .03 & $.06^{* *}$ & $.09^{* *}$ & - & & & \\
\hline 11. Parental abuse (Time 1) & $.25^{* *}$ & $.14^{* *}$ & $.07^{* *}$ & $.09^{* *}$ & $.10^{* *}$ & $.08^{* *}$ & $.10^{* *}$ & $.14^{* *}$ & $.11^{* *}$ & $.15^{* *}$ & - & & \\
\hline 12. Teacher relationship (Time 1) & $-.12^{* *}$ & $-.11^{* *}$ & $-.09^{* *}$ & $-.06^{* *}$ & $-.06^{* *}$ & -.03 & -.03 & $-.05^{*}$ & .01 & $-.15^{* *}$ & .01 & - & \\
\hline 13. Deliquent peers (Time 1) & .03 & $.04^{*}$ & $.04^{*}$ & .04 & $.30^{* *}$ & $.22^{* *}$ & $.13^{* *}$ & $.13^{* *}$ & $.11^{* *}$ & -.01 & $.07^{* *}$ & .04 & - \\
\hline
\end{tabular}

Note. Time $1=2$ nd in middle school; Time $2=3$ rd in middle school; Time $3=1$ st in high school; Time $4=2$ nd in high school; Time $5=$ 3rd in high school.

${ }^{*} p<.05 .{ }^{* *} p<.01$. 
Table 3

Latent Growth Model Fit of Adolescent Depression and Delinquency

\begin{tabular}{|c|c|c|c|c|c|c|c|c|}
\hline Variables & Change model & $\chi^{2}$ & $d f$ & $p$ & NFI & TLI & CFI & RMSEA \\
\hline \multirow[t]{3}{*}{ Depression } & Non change model & 255.31 & 11 & .000 & .87 & .88 & .87 & .10 \\
\hline & Liner change model & 130.81 & 8 & .000 & .93 & .92 & .93 & .08 \\
\hline & Quadratic curve change model & 90.66 & 4 & .000 & .95 & .88 & .95 & .10 \\
\hline \multirow[t]{3}{*}{ Delinquency } & Non change model & 633.85 & 17 & .000 & .72 & .76 & .73 & .12 \\
\hline & Liner change model & 144.37 & 14 & .000 & .93 & .94 & .94 & .06 \\
\hline & Quadratic curve change model & 51.99 & 10 & .000 & .97 & .97 & .98 & .04 \\
\hline
\end{tabular}

Table 4

Latent Growth Model Estimates of Adolescent Depression and Delinquency

\begin{tabular}{llcc}
\hline & \multicolumn{1}{c}{ Parameter } & $M(S E)$ & Variance $(S E)$ \\
\hline Depression & Intercept & $1.97(.01)^{* * *}$ & $.21(.01)^{* * *}$ \\
& Slope & $-.02(.00)^{* * *}$ & $.01(.00)^{* * *}$ \\
Delinquency & Intercept $\leftrightarrow$ Slope & & $-.56^{* * *}$ \\
& Intercept & $.19(.01)^{* * *}$ & $.11(.00)^{* * *}$ \\
& Slope & $.04(.00)^{* * *}$ & $.01(.00)^{* * *}$ \\
& Intercept $\leftrightarrow$ Slope & & $-.27^{* * *}$ \\
\hline
\end{tabular}

${ }^{* * *} p<.001$.

과 $\triangle \mathrm{RMSEA}=.02, \Delta \mathrm{TLI}=.03$ 으로 두 모형 간 적합도 차이가 거의 나지 않았다. 또한 측정 자료가 1 년마다 반복 측정된 자 료로서 다른 요인과의 발달궤적간의 관계를 밝히는 다변량 잠 재성장 모형에 보다 적합한 모형으로 선정하기 위해 선형변화 모형을 선택하였다. 이차곡선변화모형으로 발달궤적을 추정 할 경우 변화에서의 가속과 감속을 나타내는 추정치가 유의하 지 않으므로 선형변화모형이 이차곡선변화모형에 비해 자료 를 더 잘 나타낸다고 할 수 있다(Jwa, 2010).

Table 3의 분석결과를 바탕으로 선형변화모형을 최종적인 분석모형으로 설정한 후 청소년 우울과 비행의 발달궤적 초기 치, 변화율을 살펴보았다(Table 4).

전반적으로 우울은 점차 감소하였고 비행은 점차 증가하 였으며, 우울 변화율의 변량과 비행 변화율의 변량이 모두 유 의미하여 우울과 비행의 변화추이가 청소년들 간에 개인차가 있음을 알 수 있다. 우울의 초기치와 변화율은 유의미한 부적 상관 $(r=-.56, p<.001)$ 을 보여주었다. 이는 초기에 청소년 우 울 수준이 높을수록 시간의 경과에 따라 청소년 우울의 감소 가 완만하게 진행되고, 초기에 청소년 우울 수준이 낮을수록 시간의 경과에 따라 청소년 우울의 감소가 가파르게 진행됨을 알 수 있다. 비행의 초기치와 변화율의 상관관계는 부적관계 로 통계적으로 유의미한 것 $(r=-.27, p<.001)$ 으로 나타났으며,
비행의 초기치가 높은 청소년들은 완만한 증가세를 보이며 초 기치가 낮은 청소년들은 가파른 증가세를 보인다는 것을 알 수 있다.

\section{청소년기 우울과 비행의 발달궤적간 종단적 관계}

청소년 우울과 비행 발달궤적간 종단적 관계를 분석하기 위 해서 Figure 1과 같이 모형을 설정하여 두 잠재변수의 발달 궤적간 종단적 관계를 분석하였다. 이 모형의 적합도는 $\chi^{2}=$ $301.932(d f=34), p<.001, \mathrm{NFI}=.93, \mathrm{TLI}=.91, \mathrm{CFI}=.93$, $\mathrm{RMSEA}=.06(.05 \sim .06)$ 로 좋은 것으로 나타났다.

Table 5에서는 청소년 우울과 비행간 관계에서 우울과 비행 각각의 초기값과 변화율에 대한 평균과 변량을 제시하였다. 청소년 우울과 비행 발달궤적간 관계를 추정한 결과를 청소년 우울과 비행의 단일 발달궤적과 비교해 보면, 청소년 우울-비 행 다변량 발달궤적에 있어서 우울과 비행의 초기치의 평균과 변량은 동일하였다. 하지만 우울 변화율의 경우 단일 궤적에 서는 감소추세를 보였지만(Table 4 참조), 비행과 우울의 종단 적 관계를 함께 살펴본 결과 우울의 변화율은 증가하고 있으 며, 비행 또한 .04 (.00)에서 .11 (.01)로 급격하게 증가하고 있 다. 이는 청소년의 우울과 비행은 함께 발달하는 과정에서 큰 
폭으로 함께 증가한다는 것을 의미한다. 또한 청소년 우울 초 기치와 비행 초기치 그리고 청소년 우울 변화율과 비행 변화 율 변량 모두가 $p<.001$ 수준에서 유의미했다. 이는 청소년 우 울과 비행 초기값에서 개인 간 차이가 있고, 청소년 우울의 변 화율 비행의 변화율에서도 개인간 차이가 있으며, 이 차이는 통계적으로 유의미하다는 것을 뜻한다. 따라서 이러한 개인간 차이를 예측하는 변인의 투입이 가능하다고 할 수 있다.

Table 6에는 이 모형으로 추정된 각 잠재변수간의 관계에 관한 추정치가 제시되어 있다. 청소년 우울 초기치와 우울 변 화율간의 관계는 $\beta=-.55$ ( $p<.001)$ 로 유의미한 부적관계를, 우울 초기치와 비행 변화율간의 관계 또한 유의미한 부적관계 $(\beta=-.12, p<.01)$ 를 보여 우울 초기치가 높은 청소년들이 시간 의 경과에 따른 우울과 비행의 변화가 완만하게 증가하고 있 음을 나타내었다.

다음으로 청소년 비행 초기값이 비행의 변화율과 우울의 변화율에 미치는 각각의 영향을 보면, 비행 변화율에서는 $\beta$ $=-.22(p<.001)$ 로 유의미하였으며, 우울 변화율에서는 $\beta=$ -.00 ( $p=.87)$ 로 유의미하지 않은 관계를 보였다. 따라서 비 행의 초기값이 높은 청소년들이 비행의 변화가 더 완만하게 증가하고 있었다. 반면 비행의 초기값은 우울의 변화율에 영 향을 미치지 않았다. 마지막으로 청소년 우울의 초기값과 비 행의 초기값은 서로 유의미한 정적관계를 가지고 있어 청소 년 우울과 비행은 초기시점에 상호 영향을 주는 관계임이 밝 혀졌다.

\section{청소년기 우울과 비행의 발달궤적간 종단적 관계에 대한 예측변인의 영향}

청소년 우울과 비행 발달궤적에 대하여 부모학대와 부모방 임, 비행친구, 학교요인인 교사관계를 예측요인으로 투입한 모형은 Figure 2와 같다. 모형의 적합도를 보면, $\chi^{2}=367.500$ $(d f=54), p<.001, \mathrm{NFI}=.92, \mathrm{TLI}=.89, \mathrm{CFI}=.93, \mathrm{RMSEA}=$ .05 (.04 .05)로, TLI값에서 적합도를 약간 벗어나지만 CFI와 RMSEA값이 제시되는 기준값을 넘어서고 있어 비교적 적합 한 모형이라고 할 수 있다.

Table 7에는 청소년 우울과 비행의 발달궤적 및 이들의 상 호관계에 영향을 미치는 변수들을 파악하기 위해 예측변수를 투입한 모형에 대한 분석결과가 제시되어 있다. 먼저 우울 초 기값이 비행 변화율에 영향을 미치는 관계에서 예측요인을 투 입한 결과 우울의 초기값에 영향을 미치는 요인은 부모학대,

Table 5

Latent Growth Model Estimates of the Trajectories Between Adolescent Depression and Delinquency

\begin{tabular}{llcc}
\hline \multicolumn{2}{c}{ Parameter } & $M(S E)$ & Variance $(S E)$ \\
\hline Depression & Intercept & $1.97(.01)^{* * *}$ & $.21(.01)^{* * *}$ \\
& Slope & $.22(.02)^{* * *}$ & $.00(.00)^{* * *}$ \\
Delinquency & Intercept & $.19(.01)^{* * *}$ & $.11(.00)^{* * *}$ \\
& Slope & $.11(.01)^{* * *}$ & $.00(.00)^{* * *}$ \\
\hline
\end{tabular}

*** $p<.001$.

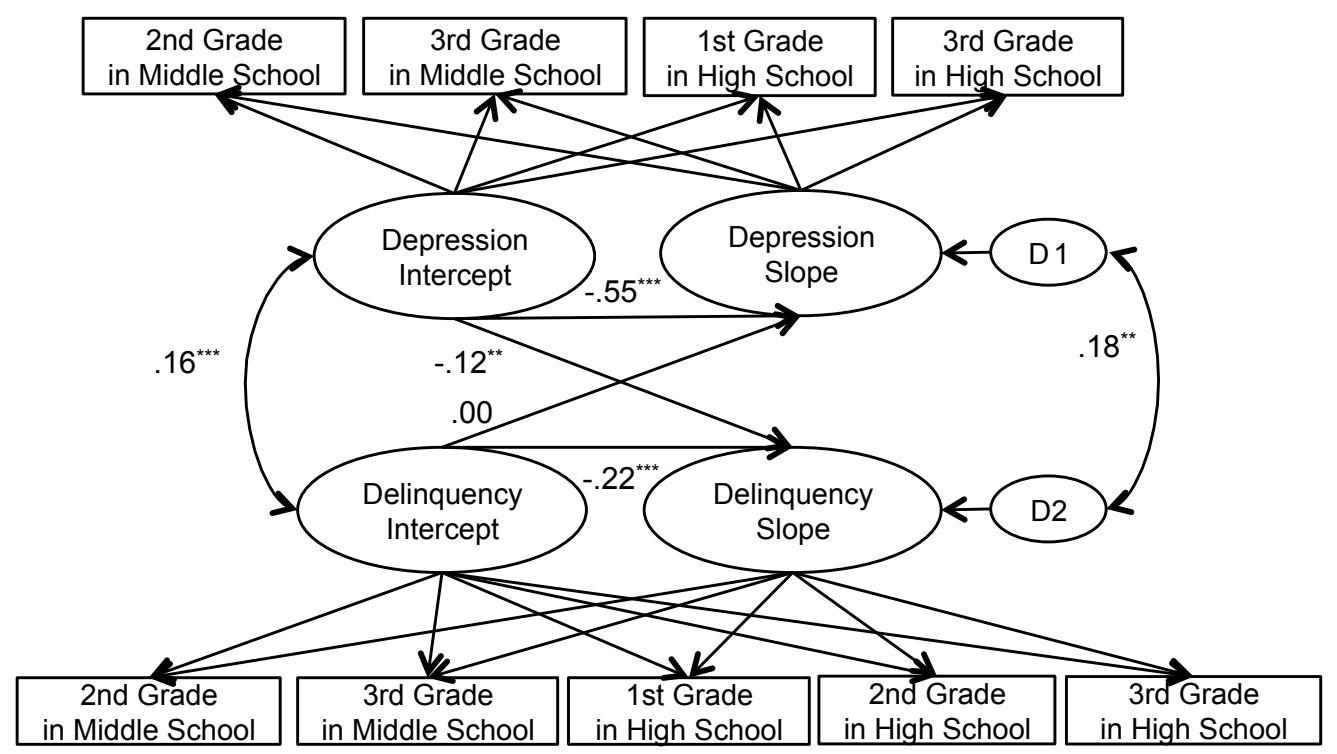

Figure 1. Longitudinal trajectories between adolescent depression and delinquency. Time $1=2$ nd in middle school; Time $2=3$ rd in middle school; Time 3 = 1st in high school; Time 4 = 2nd in high school; Time 5 = 3rd in high school. 
부모방임, 그리고 교사관계였다. 부모학대 $(\beta=.25, p<.001)$ 와 부모방임 $(\beta=.25, p<.001)$ 은 청소년의 우울과 유의미한 정적 인 관계를, 교사관계 $(\beta=-.13, p<.001)$ 는 청소년 우울과 유의 미한 부적 관계를 보여 부모의 학대 및 방임 수준이 높으며 교 사와의 관계가 원만하지 못할수록 청소년 우울의 초기치가 높 았다. 다음으로 청소년 우울의 변화율에는 부모학대와 우울의 초기값이 영향을 미치는 것으로 나타났다. 부모학대 $(\beta=-.18$, $p<.001)$ 와 우울 초기값 $(\beta=-.50, p<.001)$ 모두 우울의 변화율 과 유의미한 부적관계를 보였다. 이는 중학교 2 학년 시점의 부 모학대가 높을수록 시간이 흐름에 따라 우울이 완만하게 증가 하고 있음을 의미하며, 또한 중학교 2학년 시점의 우울이 높 을수록 시간이 흐름에 따라 우울이 완만하게 증가하는 형태로 지속되고 있음을 의미한다.
비행의 초기값에 영향을 미치는 요인은 부모학대, 비행친 구, 교사관계로 나타났다. 부모학대 $(\beta=.10, p<.001)$ 와 비행 친구 $(\beta=.41, p<.001)$ 는 비행의 초기치와 유의미한 정적인 관 계를, 교사관계 $(\beta=-.09, p<.001)$ 는 비행의 초기치와 유의미 한 부적 관계를 보이고 있어 부모의 학대 수준이 높고 비행친 구가 많으며 교사와의 관계가 원만하지 않을수록 비행의 초기 값 또한 높았다. 다음으로, 청소년의 비행 변화율과 관계가 있 는 요인은 부모학대, 부모방임, 비행친구, 청소년 비행 초기치 그리고 청소년 우울 초기치였다. 부모학대 $(\beta=.14, p<.001)$ 와 부모방임 $(\beta=.12, p<.001)$ 은 청소년 비행의 변화율과 정적 이고 유의미한 관계를, 비행친구 $(\beta=-.15, p<.001)$, 비행 초기 치 $(\beta=-.17, p<.01)$ 와 우울 초기치 $(\beta=-.20, p<.001)$ 는 비행의 변화율과 부적이고 유의미한 관계를 나타내었다. 이는 부모학

Table 6

Latent Growth Model Estimates of Latent Variables Between Adolescent Depression and Delinquency

\begin{tabular}{|c|c|c|c|c|}
\hline Parameter & $B$ & $\beta$ & $S E$ & C.R. \\
\hline Depression intercept $\rightarrow$ Depression slope & -.12 & $-.55^{* * *}$ & .01 & -10.56 \\
\hline Depression intercept $\rightarrow$ Delinquency slope & -.02 & $-.12^{* *}$ & .00 & -2.93 \\
\hline Delinquency intercept $\rightarrow$ Delinquency slope & -.06 & $-.22^{* * *}$ & .01 & -3.96 \\
\hline Delinquency intercept $\rightarrow$ Depression slope & -.00 & -.00 & .01 & -0.16 \\
\hline Depression intercept $\rightarrow$ Delinquency intercept coefficient of correlation & .02 & $.16^{* * *}$ & .00 & 4.32 \\
\hline
\end{tabular}
${ }^{* *} p<.01 .{ }^{* * *} p<.001$.

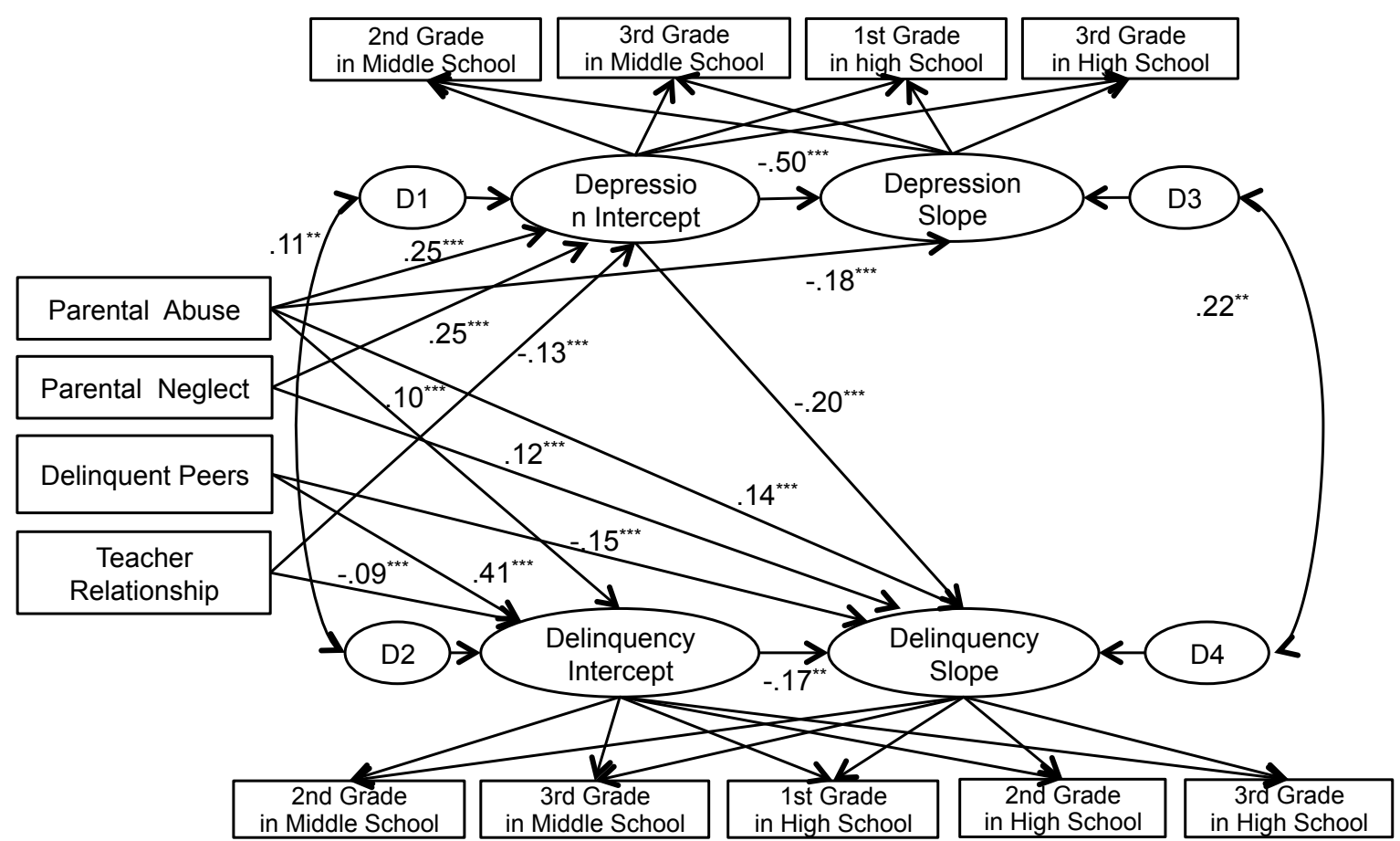

Figure 2. Predictors of longitudinal trajectories between adolescent depression and delinquency. Time $1=2$ nd in middle school; Time $2=$ 3rd in middle school; Time 3 = 1st in high school; Time $4=2$ nd in high school; Time 5 = 3rd in high school. 
Table 7

Latent Growth Model Path Coefficient Estimates of Predictors

\begin{tabular}{|c|c|c|c|c|c|c|c|c|}
\hline & \multicolumn{4}{|c|}{ Intercept } & \multicolumn{4}{|c|}{ Slope } \\
\hline & $B$ & $\beta$ & $S E$ & C.R. & $B$ & $\beta$ & $S E$ & C.R. \\
\hline \multicolumn{9}{|l|}{ Depression } \\
\hline Parental abuse & .16 & $.25^{* * *}$ & .01 & 10.05 & -.02 & $-.18^{* * *}$ & .00 & -4.59 \\
\hline Parental neglect & .21 & $.25^{* * *}$ & .01 & 9.70 & .00 & -.02 & .00 & -2.30 \\
\hline Delinquent peers & .00 & .03 & .00 & 1.54 & .00 & .04 & .00 & 0.36 \\
\hline Teacher relationship & -.09 & $-.13^{* * *}$ & .01 & -5.29 & .00 & .05 & .00 & 1.46 \\
\hline Depression intercept & & & & & -.11 & $-.50^{* * *}$ & .01 & -8.18 \\
\hline Delinquency intercept & & & & & -.00 & -.00 & .01 & 0.92 \\
\hline \multicolumn{9}{|l|}{ Delinquency } \\
\hline Parental abuse & .04 & $.10^{* * *}$ & .01 & 3.56 & .02 & $.14^{* * *}$ & .00 & 4.14 \\
\hline Parental neglect & .00 & .01 & .01 & 0.34 & .02 & $.12^{* * *}$ & .00 & 3.50 \\
\hline Delinquent peers & .06 & $.41^{* * *}$ & .00 & 14.92 & -.00 & $-.15^{* * *}$ & .00 & -3.72 \\
\hline Teacher relationship & -.04 & $-.09^{* * *}$ & .01 & -3.29 & .00 & .01 & .00 & 0.48 \\
\hline Delinquency intercept & & & & & -.05 & $-.17^{* *}$ & .01 & -2.67 \\
\hline Depression intercept & & & & & -.04 & $-.20^{* * *}$ & .01 & -4.16 \\
\hline
\end{tabular}

Note. $\chi^{2}=367.500(d f=54), p<.001, \mathrm{NFI}=.92, \mathrm{TLI}=.89, \mathrm{CFI}=.93, \mathrm{RMSEA}=.05(.04 \sim .05)$.

${ }^{* *} p<.01 .{ }^{* * *} p<.001$.

대와 방임 수준이 높을수록 청소년 비행의 변화는 가파르게 증가하였으며, 비행친구가 많으며 우울과 비행 수준이 초기에 높은 청소년들은 학년이 높을수록 비행행동을 지속시키는 경 향을 나타내었다. 마지막으로 우울과 비행의 종단적 관계에 영향을 미치는 요인으로는 부모학대, 부모방임, 교사관계가 나타났다. 부모학대 $(\beta=.25, p<.001)$ 와 부모방임 $(\beta=.25, p<$ .001)은 우울의 초기치에 정적이고 유의미한 관계를 교사관계 $(\beta=-.13, p<.001)$ 는 우울의 초기치에 부적이고 유의미한 관 계를 나타냈으며, 우울의 초기치 $(\beta=-.22, p<.001)$ 는 다시 비 행의 변화율에 부적이고 유의미한 영향을 미쳤다. 즉 부모학 대와 부모방임 수준이 높고 교사관계에서 부정적으로 지각할 수록 청소년의 우울 수준이 높으며 이는 중학교 2학년에서 고 등학교 3학년까지 비행을 완만하게 증가시켰다.

\section{논의}

본 연구는 잠재성장모형 분석을 통해 중학교 2학년부터 고등 학교 3학년까지 5년 동안의 우울 및 비행의 시간경과에 따른 발 달궤적을 추정하고, 우울과 비행의 발달궤적이 종단적으로 어 떠한 관련성을 지니고 있는지를 분석하였으며, 이러한 상호적 관련성에 영향을 미치는 부모, 또래, 교사요인의 영향력을 규명
하였다. 연구결과들을 요약하고 이에 대한 논의는 다음과 같다.

첫째, 청소년 우울과 비행의 발달궤적을 추정한 결과 우선 우울은 중학교 2학년부터 고등학교 3학년까지 점차 감소하 는 추세를 보였으며 이는 대부분의 선행연구 결과와 일치한 다(Jwa, 2010; H. Lim \& Choi, 2010; Meadows, Brown, \& Elder, 2006). 이러한 결과는 학년이 높아짐에 따라 자신의 정서를 다 루는 능력이 향상되고, 인지 및 행동적인 대처양식 그리고 사 회적지지 기반 등 여러 심리학적 적응 수준이 중학생 시기에 비해 고등학생 시기에 발달하여 위기상황에 보다 적응적으 로 대처함으로써 우울이 점차 감소했기 때문이다(Y. A. Lee \& Chung, 2015). 다음으로 청소년 비행의 발달궤적을 추정한 결 과, 중학교 2학년부터 고등학교 3학년까지 비행은 점차 증가 하는 추세를 보이고 있었으며 이는 국내에서 초등학교 5학년 에서 중학교 1학년까지 비행을 포함한 외현화 문제행동이 증 가한다(Y. Kim \& Lee, 2015)는 연구 결과와 같은 맥락으로 이 해할 수 있으며, 중학교 2학년부터 고등학교 3학년까지 음주, 흡연 가출 등으로 구성된 경비행행동이 증가한다는 연구결과 (S.-G. Lee, 2009)와 부분적으로 일치한다. 이러한 결과를 살펴 보면 본 연구에서는 흡연, 음주, 가출 등에 해당하는 경비행과 폭행, 패싸움, 절도 등 중비행을 동일한 점수로 합산하여 사용 하였는데, 연령이 높아지면서 성인의 행동을 모방하고자하는 흡연, 음주 등의 지위비행이 증가함에 따라 전체적인 비행수 
준이 증가하였을 것이라고 해석할 수 있다.

둘째, 청소년 우울과 비행의 발달궤적 간의 관계를 살펴보 면 초기시점 우울은 비행의 변화율에 영향을 미쳤으나 초기시 점 비행은 우울의 변화율에 영향을 미치지 않는 것으로 나타났 다. 이러한 결과는 우울과 비행의 관계를 설명하는 모델 중 우 울이 비행을 유발한다는 행동화(acting out) 모델을 뒷받침하는 선행연구 결과들(Beyers \& Loeber, 2003; Kofler, et al., 2011)과 맥을 같이 하는 것이다. 이는 청소년 우울 증상의 특징인 가면 성 우울(masked depression)로 설명할 수 있는데, 청소년들의 비 행은 내재화된 우울증상이 외현적으로 표현된 것이라고 본다 (Carlson \& Cantwell, 1980). 또한 본 연구에서 대상은 중학생에 서 고등학생 시기까지이며 이 시기에는 주로 상호작용하는 대 상이 부모에서 또래로 옮겨지고 또래와의 관계가 더욱 공고해 지는 시기이다. 이러한 맥락에서 행동화모델을 살펴보면 청소 년들이 경험하는 우울이 다소 공격적이고 비행행동으로 표출 되었을 때 이로 인해 부모와의 갈등이 발생하게 되고 부모와의 관계에서 발생한 갈등을 해소하기 위해 일탈행동을 하는 또래 와 더 자주 어울리게 되고 심각한 비행행동을 하게 된다는 것 이다(Poirier et al., 2016). 따라서 청소년의 우울과 비행이 더 심 각해지고 지속되는 것을 막기 위해 우울을 보이는 청소년들을 조기에 발견하여 개입하는 접근이 우선시되어야 한다.

셋째, 다변량 잠재성장 조건모형을 활용하여 우울과 비행 의 발달궤적간 종단적 관계에 예측요인들을 투입하여 분석 한 결과는 다음과 같다. 부모학대는 우울과 비행의 초기치 모 두에 정적인 영향을 미쳤으며 우울의 변화율에는 부적인 영 향을 비행의 변화율에는 정적인 영향을 미쳤다. 먼저, 부모의 학대 수준이 높을수록 초기 시점 청소년의 우울 및 비행 수준 이 높다는 연구결과는 대다수의 선행연구결과(M. Kim, 2016; Lansford et al., 2007; Moretti \& Craig, 2013)와 일치하였으며, 부모학대가 청소년의 우울 및 비행에 공동으로 관계된다는 선행연구결과(S.-H. Jung, 2009; Keiley, Bates, Dodge, \& Pettit, 2000)와 유사한 맥락이었다.

또한 부모학대는 우울의 증가율을 완만하게 하고 비행의 증가율은 가파르게 하는 위험요인으로 기능하고 있었으며 이 는 기존의 선행연구와 유사하였다(B. Lee \& Min, 2014; E.-J. Lee, 2010). E.-J. Lee (2010)의 연구에서는 초등학교 4학년의 자 녀학대와 내재화 행동문제간의 관계에서 초기 시점 자녀학대 는 이후의 내재화 문제의 증가를 완만하게 하였다. 이는 본 연 구와 유사한 결과로 학대를 경험한 청소년들은 가정의 억압 된 분위기 속에서 자신의 정서를 통제하고 억압해야 하는 것으 로 생각하여 자신의 정서를 인식하는데 무감각하기 때문에(Y.
Son, 2007) 우울 점수가 과소평가되어 변화율이 완만하게 증가 하였을 가능성이 있다. 반면 부모학대가 비행의 변화율을 가파 르게 증가시킨다는 연구결과는 비행의 경우 흡연 및 음주 여부 와 같이 자신의 행동상의 문제에 대한 구체적인 문항으로 구성 되어 우울에 비해 부모학대가 청소년 비행을 증가시키는 현상 이 보다 실제적으로 규명되었을 것이라고 추정해 볼 수 있다.

다음으로 부모방임 수준이 높을수록 초기 시점의 우울이 높게 나타난 결과는 부모방임이 청소년의 우울이나 내재화 문 제를 유발한다는 국.내외 선행연구(Francke, Viola, Tractenberg, \& Grassi-Oliveira, 2013; Kim, 2016; S. A. Lim, 2015)들과 맥을 같이 한다. 반면, 부모방임이 동일 시점 청소년의 비행에 영향 을 주지 않는다는 결과는 부모감독이 동일 시점 중학교 2학 년 남자청소년의 비행에는 영향을 미치지 않는다는 선행연구 와 부분적으로 일치한다(Seo \& Kim, 2015). 이러한 결과는 부 모방임 외에 청소년 비행에 영향을 미치는 부모학대, 비행친 구와 같은 더욱 강력한 변인의 투입으로 부모방임의 영향력이 상쇄되었을 가능성을 제기할 수 있다. 한편, 부모방임은 비행 의 변화율에 정적인 영향을 미쳐 청소년 비행을 가파르게 증 가시키는 요인으로써 작용하였다. 이는 이전에 경험한 부모 의 방임이 청소년 시기의 공격성이나 비행을 예측하고 강화시 킨다는 연구결과들(M. Kim, 2016; S. A. Lim. 2015)과 맥을 같 이 한다. 특히 Kerr, Stattin과 Burk (2010)는 부모가 자녀의 또 래 관계 및 학교생활에 관심을 덜 가지고 대화를 덜 나눌수록 이후의 비행행동이 높아졌다고 밝혔다. 이러한 결과는 부모가 자녀에 대해 관심을 가지고 감독하지 않을 때 자녀는 자신들 의 행동을 통제하지 못하게 되거나 자신에게 관심이 없고 냉 담한 부모에 대해 반항적인 행위로써 비행을 하게 된다고 해 석할 수 있다(M. Kim, 2016).

다음으로, 비행친구는 우울의 초기치와 변화율에는 유의한 영향을 미치지 않았으나 비행의 초기치와 변화율에는 모두 유 의한 영향을 미쳤으며 영향력의 정도도 가장 크게 나타났다. 이러한 결과는 청소년 비행에 있어 또래요인인 비행친구가 가 장 큰 위험요인으로 작용한다는 선행연구(Church et al., 2012; S.-H. Jung, 2009)와 맥을 같이 한다. Akers (1998)의 사회학습이 론(social learning theory) 중 차별접촉(differential association)에 근거하여 살펴보면, 인간은 중립적인 존재이기에 이들의 행동 은 타인 및 집단과의 상호작용의 결과로써 형성된다. 즉 비행 과 무관했던 청소년들이 비행에 대해 긍정적인 태도나 규범을 가진 친구들과의 상호작용을 통해 비행을 하게 된다는 것이다. 따라서 청소년의 비행에 적절한 개입을 하기 위해서는 비행친 구의 영향력을 함께 고려한 개별적인 접근이 필요하다. 
교사관계가 청소년 우울 및 비행의 발달궤적에 미치는 영 향을 살펴본 결과 교사와의 관계가 원만할수록 초기시점 우울 과 비행 수준을 낮추는 효과를 보였으나 변화율에는 영향을 미치지 않았다. 이러한 결과는 가정 및 또래 외에 교사와의 관 계가 동일시점 청소년의 정서 및 행동적 적응에 중요한 역할 을 한다고 보고한 횡단연구들(Cho, 2009; M.-Y. Kim \& Jung, 2015)과 일치한다. 이는 청소년들이 가장 많은 시간을 보내는 학교에서 교사와의 관계 또한 청소년기 우울 및 비행을 예방 할 수 있는 중요한 안전기저임을 보여주는 것으로써, 교사와 의 긍정적인 관계는 여러 부적응적인 요인을 감소시키고 청소 년의 적응적인 성장을 돕는다(J. B. Kim, 2012). 따라서 청소년 우울 및 비행에 효과적으로 개입하기 위해서는 교사와의 관계 증진 또한 중요한 과제임을 시사하고 있는 것이다. 한편, 교사 관계는 청소년 우울 및 비행의 변화율에 직접적인 영향을 미 치지 않았다. 이는 중학교 2학년 초기시점 교사에 대한 지각만 을 예측요인으로서 측정하였으며, 학년이 올라감에 따라 담임 교사가 바뀌는 학교현장을 고려하였을 때 교사에 대한 지각은 매년 바뀌기 때문에 청소년의 우울과 비행의 변화에 영향을 주지 않았을 것이라고 추정해 볼 수 있다.

마지막으로 우울의 초기치가 비행의 변화율의 증가를 완만 하게 하는 종단적 관계에 영향을 미치는 요인으로 부모학대, 부 모방임 그리고 교사관계가 나타났다. 이러한 결과는 동일시점 부모학대가 높을수록(Moretti \& Craig, 2013) 부모방임이 높을 수록(S. A. Lim, 2015) 교사와의 관계가 부정적일수록(M.-Y. Kim \& Jung, 2015) 청소년의 우울수준이 높다고 보고한 횡단연구들 과 일치한다. 또한 자녀학대수준이 높을수록 부모의 지도감독 수준이 낮을수록 내재화 문제의 초기치가 높으며 이는 다시 외 현화 문제의 변화율에 영향을 준다는 E.-J. Lee (2010)의 연구와 부분적으로 일치한다. 이는 부모학대와 방임 같은 부정적인 양 육태도와 교사와의 부정적인 관계는 중학교 2 학년 학생의 우 울 수준에 영향을 미치며 자신의 부정적인 감정을 다루는데 이 를 비행행동으로 표현하게 되는 것이라고 해석할 수 있다.

다음으로 본 연구의 의의에 대해서 살펴보고자 한다. 첫째, 종단 연구를 통해 우울과 비행의 시간이 흐름에 따른 변화 추 이를 밝힐 수 있었으며, 청소년기 전반에 걸쳐서 다루었다는 점에 의의를 둘 수 있다. 둘째, 우울과 비행 모두에 영향을 미 치는 변인으로 부모요인 중 부모학대로 나타나, 부모학대가 청소년의 우울 및 비행을 지속, 증가시키는 중요한 변인임을 알 수 있었다. 따라서 청소년 우울과 비행을 예방하고 치료적 개입을 위해 가정 내의 부모양육태도에 대한 관심이 필요하 며 학대적 양육이 이루어지는 경우 이에 적절한 개입이 필요
하다. 셋째, 청소년기 우울과 비행을 다룬 많은 선행연구에서 우울과 비행을 분리시켜 관련변인들의 영향력을 규명하는데 그쳤다면, 본 연구에서는 우울과 비행의 발달궤적간의 관계를 함께 살펴보고, 이에 영향을 미치는 부모, 또래, 교사요인을 규 명하였다는데 의의가 있다. 이를 통해 우울이 동반된 비행은 더욱 위험하다는 가능성을 제기할 수 있었으며 청소년 비행의 근본적인 해결 및 치료 전략을 세울 때 우울 뿐만 아니라 부모, 또래, 교사요인 등 관련 변인들의 영향력을 고려하여 접근해 야함을 시사하였다.

이상과 같은 함의에도 불구하고 본 연구는 몇 가지 제한점 을 가지고 있다.

첫째, 본 연구의 분석에 사용된 한국아동 - 청소년패널 자료 에서 비행 문항의 신뢰도가 낮게 산출되었다는 점이다. 이는 패널조사 특성상 원척도를 사용하기 보다는 원척도에서 관련 문항을 추출하여 사용하여 비행이 대표하는 속성을 제대로 측 정하는데 한계가 있었기 때문이다. 추후 연구에서는 신뢰도가 확보된 도구를 사용할 필요가 있다.

둘째, 본 연구는 청소년의 경비행과 중비행을 구분하지 않 고 통합하였다는 데 제한점이 있다. 선행연구에 의하면 흡연 행위와 같은 경비행의 경우 자기통제력과 비행친구의 영향 이, 폭력행위와 같은 중비행의 경우 부모-자녀 학대 요인이 추 가로 영향을 미치는 것으로 나타났으며(J. K. Lee, 2012), 경비 행과 중비행에 따라 청소년의 비행 발달양상이 상이하며 관 련변인들의 영향력이 차이가 있다는 근거(Brown, Catalano, Fleming, Haggerty, \& Abbott, 2005)를 토대로, 후속 연구에서는 청소년의 비행의 정도를 구분하여 살펴볼 필요성이 있다.

셋째, 본 연구는 교사관계를 초기 시점만을 측정하여 예측요 인으로 투입하였다. 이는 초등학생의 경우 학년마다 담임교사 가 달라짐에도 불구하고 교사와의 관계에서 신뢰와 같은 긍정 적인 자원들이 일관성 있게 지각하고 있었다는 B.-S. Jung (2011) 의 연구를 토대로 교사관계를 초기 예측요인으로 설정하였다. 하지만 학년마다 담임교사가 달라지는 학교현장을 고려하였 을 때 교사관계는 시간 의존적 변수로서 고려될 필요가 있다.

마지막으로 본 연구는 전국의 중·고등학교 재학생을 대상 으로 한 패널 조사로 대체로 우울과 비행 수준이 낮다는 것이 다. 이는 우울과 비행 고위험군에 해당되는 청소년들이 학교 에서 이탈되었을 경우 패널자료에 포함되지 않았을 가능성을 제기할 수 있다. 학교에서 이탈된 경우로 청소년의 가출 혹은 학업중단 등이 있을 수 있다. 이들의 우울과 비행수준은 재학 중인 학생들 보다 상대적으로 높고 환경적으로도 취약하므로 (Keum, 2008) 추후 연구에서는 이러한 고위기청소년을 대상 
으로 한 우울과 비행의 발달궤적을 살펴볼 필요성이 있다.

\section{Conflict of Interest}

No potential conflict of interest relevant to this article was reported.

\section{References}

\section{In English}

Akers, R. L. (1998). Social learning and social structure: A general theory of crime and deviance. Boston: Northeastern University Press.

Beyers, J. M., \& Loeber, R. (2003). Untangling developmental relations between depressed mood and delinquency in male adolescents. Journal of Abnormal Child Psychology, 31(3), 247-266. doi:10.1023/A:1023225428957

Bowlby, J. (1958). The nature of the child's tie to his mother. The International Journal of Psycho-Analysis, 39(5), 350-373.

Bronfenbrenner, U. (1979). Contexts of child rearing: A problems and prospects. American Psychologist, 34(10), 844-850. doi:10.1037/0003-066X.34.10.844

Brown, E. C., Catalano, R. F., Fleming, C. B., Haggerty, K. P., \& Abbott, R. D. (2005). Adolescent substance use outcomes in the raising healthy children project: A twopart latent growth curve analysis. Journal of Consulting and Clinical Psychology, 73(4), 699-710. doi:10.1037/0022006X.73.4.699

Capaldi, D. M. (1991). Co-occurrence of conduct problems and depressive symptoms in early adolescent boys: I. Familial factors and general adjustment at grade 6. Development and Psychopathology, 3(3), 277-300. doi:10.1017/ S0954579400005319

Carlson, G. A., \& Cantwell, D. P. (1980). Unmasking masked depression in children and adolescents. American Journal of Psychiatry, 137(4), 445-449. doi:10.1176/ajp.137.4.445

Church II, W. T., Tomek, S., Bolland, K. A., Hooper, L. M., Jaggers, J., \& Bolland, J. M. (2012). A longitudinal examination of predictors of delinquency: An analysis of data from the Mobile Youth Survey. Children and Youth Services Review, 34(12), 2400-2408. doi:10.1016/ j.childyouth.2012.09.007

Fergusson, D. M., Wanner, B., Vitaro, F., Horwood, L. J., \& Swain-Campbell, N. (2003). Deviant peer affiliations and depression: Confounding or causation?. Journal of Abnormal Child Psychology, 31(6), 605-618. doi:10.1023/

\section{A: 1026258106540}

Francke, I. D. A., Viola, T. W., Tractenberg, S. G., \& GrassiOliveira, R. (2013). Childhood neglect and increased withdrawal and depressive severity in crack cocaine users during early abstinence. Child Abuse \& Neglect, 37(10), 883-889. doi:10.1016/j.chiabu.2013.04.008

Gilliom, M., \& Shaw, D. S. (2004). Codevelopment of externalizing and internalizing problems in early childhood. Development and Psychopathology, 16(2), 313-333. doi: $10.1017 /$ S0954579404044530

Glaser, K. (1967). Masked depression in children and adolescents. American Journal of Psychotherapy, 21(3), 565-574.

Herrero, J., Estévez, E., \& Musitu, G. (2006). The relationships of adolescent school-related deviant behaviour and victimization with psychological distress: Testing a general model of the mediational role of parents and teachers across groups of gender and age. Journal of Adolescence, 29(5), 671-690. doi:10.1016/j.adolescence.2005.08.015

Keiley, M. K., Bates, J. E., Dodge, K. A., \& Pettit, G. S. (2000), A cross-domain growth analysis: Externalizing and internalizing behaviors during 8 years of childhood. Journal of Abnormal Child Psychology, 28(2), 161-179. doi:10.1023/ A: 1005122814723

Kerr, M., Stattin, H., \& Burk, W. J. (2010). A reinterpretation of parental monitoring in longitudinal perspective. Journal of Research on Adolescence, 20(1), 39-64. doi:10.1111/j.15327795.2009.00623.x

Kline, R. B. (2015). Principles and practice of structural equation modeling (4th ed.). New York: Guilford Publications.

Kofler, M. J., McCart, M. R., Zajac, K., Ruggiero, K. J., Saunders, B. E., \& Kilpatrick, D. G. (2011). Depression and delinquency covariation in an accelerated longitudinal sample of adolescents. Journal of Consulting and Clinical Psychology, 79(4), 458-469. doi:10.1037/a0024108

Lansford, J. E., Miller-Johnson, S., Berlin, L. J., Dodge, K. A., Bates, J. E., \& Pettit, G. S. (2007). Early physical abuse and later violent delinquency: A prospective longitudinal study. Child Maltreatment, 12(3), 233-245. doi: $10.1177 / 1077559507301841$

Leadbeater, B., Thompson, K., \& Gruppuso, V. (2012). Cooccurring trajectories of symptoms of anxiety, depression, and oppositional defiance from adolescence to young adulthood. Journal of Clinical Child and Adolescent Psychology, 41(6), 719-730. doi:10.1080/153744416.2012.694608

Liljeberg, J. F., Eklund, J. M., Fritz, M. V., \& af Klinteberg, B. (2011). Poor school bonding and delinquency over time: Bidirectional effects and sex differences. Journal of Adolescence, 34(1), 1-9. doi:10.1016/j.adolescence.2010.03.008

Meadows, S. O., Brown, J. S., \& Elder, G. H. (2006). Depressive symptoms, stress, and support: gendered trajectories from 
adolescence to young adulthood. Journal of Youth and Adolescence, 35(1), 89-99. doi:10.1007/s10964-005-9021-6

Moretti, M. M., \& Craig, S. G. (2013). Maternal versus paternal physical and emotional abuse, affect regulation and risk for depression from adolescence to early adulthood. Child Abuse and Neglect, 37(1), 4-13. doi:10.1016/ j.chiabu.2012.09.015

Patterson, G. R., Reid, J. B., \& Dishion, T. J. (1992). A Social Interacitonal Approach Vol. 4: Antisocial boys. Eugene: Castalia Pub Co.

Poirier, M., Déry, M., Temcheff, C. E., Toupin, J., Verlaan, P., \& Lemelin, J. P. (2016). Longitudinal associations between conduct problems and depressive symptoms among girls and boys with early conduct problems. European Child \& Adolescent Psychiatry, 25(7), 743-754. doi:10.1007/s00787015-0796-z

Rathi. N., \& Rastogi. R. (2007). Meaning in life and psychological well-being in pre-adolescents and adolescents. Journal of the Indian Academy of Applied Psychology, 33(1), 31-38.

Rudolph, K. D., Flynn, M., Abaied, J. L., Groot, A., \& Thompson, R. (2009). Why is past depression the best predictor of future depression? Stress generation as a mechanism of depression continuity in girls. Journal of Clinical Child \& Adolescent Psychology, 38(4), 473-485. doi:10.1080/15374410902976296

Wiesner, M. (2003). A longitudinal latent variable analysis of reciprocal relations between depressive symptoms and delinquency during adolescence. Journal of Abnormal Psychology, 112(4), 633-645. doi:10.1037/0021843X.112.4.633

\section{In Korean}

Cho, J.-A. (2009). The effects of parents, peers and teachers upon changes in mental health on the part of adolescents: A focused on depression and anxiety. Studies on Korean Youth, 20(3), 167-192.

Choi, J.-A. (2010). The reciprocal causation between delinquency and depression during early adolescence : testing autoregressive cross-lagged effects. Studies on Korean Youth, 21(4), 143-169.

Chung, S. S., Lee, K. H., Lee, S. S. (2005). A Study on split variable selection using transformation of variables in decision trees. Journal of the Korean Data \& Information Science Society, 16(2), 195-205.

Heo, M. Y. (2000). The study for the development and validation of 'parenting behavior inventory' perceived by adolescent (Doctoral dissertation). Retrieved from http://www.riss.kr/ link?id=T10397901

Hong, S. (2000). The criteria for selecting appropriate fit indices in structural equation modeling and their rationales. Korean
Journal of Clinical Psychology, 19(1), 161-177.

Joo, S. Y., \& Lee, Y. H. (2012). The roles of student-teacher attachment between Latent delinquency, negative automatic thought and resilience in adolescents. Korea Journal of Youth Studies, 19(8), 103-142. Retrieved from http://www.riss. $\mathrm{kr} / \mathrm{link}$ ? id=A102952003

Jung, B.-S. (2011). Developmental trajectories of early adolescents' trust and closeness with their teachers from the 4th through to the 8th grade). Studies on Korean Youth, 22(4), 63-89.

Jung, S.-H. (2009). A study on the factors affecting delinquency trajectories. Studies on Korean Youth, 20(2), 31-64.

Jwa, H. (2010). Risk factors and protective factors on internalizing problem of adolescents. Korea Journal of Youth Studies, 17(10), 105-133.

Keum, M.-J. (2008). Comprehensive understanding about dropout adolescents in Korea. Korean Journal of Psychological and Social Lssues, 14(1), 299-317.

Kim, G. I., Kim, J. H., \& Won, H. T. (1984). Korean manual of symptom checklist-90-revision. Seoul: Chungang Aptitude Publishing Company.

Kim, J. B. (2012). Effects of student-teacher relationship on students' psychological resilience. The Korean Journal of Educational Psychology, 26(2), 523-541.

Kim, J., No, S., Lee, S., Gwak, D., Park, J., Lee, D., \& Park, C., (2013). cheongsonyeon bihaengnon[adolescence delinquency] (3rd), Seoul: Chongmok Books.

Kim, J.-H., \& Lee, D.-W. (1995). The study on the Juvenile Delinquency Scales in Korea. Korean Institute of Criminology, 9-179.

Kim, J. Y., \& Choi, K. H. (2012). The co-occurrence of child physical abuse and neglect. Journal of Adolescent Welfare, 14(3), 193-213

Kim, M. (2016). Stability and reciprocal effects of parental abuse and neglect and adolescent depression and delinquency (Doctoral dissertation). Retrieved from http://www.riss.kr/ link?id=T14138703

Kim, M.-Y., \& Jung, H.-H. (2015). The relation between children's self-esteem and depression: Mediating effects of teacher and peer attachment. The Journal of Child Education, 24(3), 101-116.

Kim, S. (2003). The effect of social support on abused children's adjustment (Master's thesis). Retrieved from http://www. riss.kr/link?id=T8876131

Kim, Y. \& Lee, J. (2015). Study on adolescents' internalizing and externalizing problem behaviors and related variables in transition with latent growth model. Journal of Korean Home Management Association, 33(1), 1-17.

Koo, J. G. (2004). The relationship between school related psychosocial characteristics and mental health. Korean Journal of Youth Studies, 11(2), 217-239. 
Lee, A.-Y., \& Yoo, S. G. (2011). Influences of exposures to marital violence and child abuse on aggression of early adolescents: Findings from Korean youth panel study (KYPS). Journal of Adolescent Welfare, 13(2), 225-245.

Lee, B., \& Min, W. (2014). A longitudinal study of the effects of child maltreatment on children's developmental outcomes. Journal of Korean Council for Children \& Rights, 18(2), 163-195.

Lee, E.-J. (2010). Longitudinal co-development of internalizing and externalizing problem behaviors: A cross-domain latent growth curve modeling approach. Studies on Korean Youth, 21(4), 171-200.

Lee, J. K. (2012). A longitudinal effects of parent attachment, peer attachment and teacher attachment on delinquency in adolescence. Journal of Youth Welfare, 14(2), 51-73.

Lee, J. R. (2008). Adolescents' attachments to parents, teachers, and friends, and delinquencies. Korean Journal of Human Ecology, 17(4), 563-574.

Lee, J. W. (2013). A longitudinal analysis on relations among youths' academic achievement, delinquent behavior and delinquent friends (Report No. 13-R14-1). National Youth Policy Institute. Retrieved from http://www.dbpia.co.kr/Article/ NODE02361276

Lee, J.-Y., (2010). Codevelopment of depression and delinquency in early adolescence: The effects of temperaments (Doctoral dissertation). Retrieved from http://www.riss.kr/ link? id=T12185003

Lee, K.-N. (2003). The effects of attachment and depression on the adolescent delinquency. Korean Journal of Human Ecology, 12(1), 1-13.

Lee, S.-G. (2009). Parallel process latent growth modeling of parent influences on delinquent behaviors in adolescence. Korean Journal of Family Social Work, 27(0), 243-266.

Lee, S., \& Heo, M. (2015). The analysis of longitudinal causal relationship between depression and delinquency in adolescents. Journal of Youth Welfare, 17(2), 241-264.

Lee, Y. A., \& Chung, H. H. (2015). Longitudinal sutdy of the developmental tragectories of internalizing and externalizing problem and the impact factors on the phase in adolescent's behavior. The Korea Journal of Youth Counseling, 23(2), 253-276.

Lim, H., \& Choi, S. (2016). Developmental trajectories and predictors of adolescent depression : A short-term study. Korean Journal of Psychology: General, 35(3), 455-480.

Lim, S. A. (2015). Effects of child maltreatment on delinquency by the mediation role of psychosocial adaptation: Moderating effect of family income. Journal of Korean Society of Child Welfare, 50, 85-108.
Lim, S. W. (2013). A longitudinal study on the effects of social capital on depression among adolescents: The mediating effects of selfesteem (Master's thesis). Retrieved from http://www.riss.kr/ link?id=T13241000

Min, B. S. (1991). The effect of school life adaptation and self-concept on academic achievement (Master's thesis). Retrieved from http://www.riss.kr/link?id=T2167733

Min, W., \& Lee, B. (2015). A longitudinal study to examine the relationship between poverty and the internalization of problems in adolescence. Studies on Korean Youth, 26(1), 145-169.

Park, J. (2011). The longitudinal analysis of the relationship between teacher attachment and students' maladjustment to schools. The Journal of Korean Teacher Education, 28(3), 333-352.

National Youth Policy Institute. (2012-2016). Korea Children and Youth Panel Survey 1-7th survey of 7th grade [Data file and code book]. Retrieved from http://www.nypi.re.kr/

National Youth Policy Institute. (2016). Korea Children and Youth Panel Survey 1-7th survey [User's guide]. Retrieved from http://www.nypi.re.kr/

Seo, B., \& Kim, K. (2015). The longitudinal relationship between juvenile delinquent behaviors and parental monitoring across gender group. Forum for Youth Culture, 41(1), 87-108.

Sin, Y., \& Hwang, S. (2016). Examining the causal relationship between mental health problems and school adjustment during adolescence using an autoregressive cross-lagged modeling. Journal of Youth Welfare, 18(2), 1-19.

Son, K. (2007). The development and verification of effect of the emotion regulation competence improving group counseling program for group home children's (Doctoral dissertation). Retrieved from http://www.riss.kr/link?id=T11004867

Son, Y. (2016). Effects of delinquent peer association on juvenile delinquency: Focusing on the moderate effect of self-control (Master's thesis). Retrieved from http://www.riss.kr/ link?id=T14067081

\section{ORCID}

Son Ji Ah

Kim Sun Hee https://orcid.org/0000-0002-6014-0297

https://orcid.org/0000-0002-0801-6918
Received August 6, 2017

Revision received November 14, 2017

Accepted November 22, 2017 
